\title{
PERBEDAAN PENGARUH PEMBELAJARAN PROBLEM POSING MELALUI TUTORIAL ONLINE DAN TATAP MUKA TERHADAPPRESTASI BELAJAR DITINJAU DARI TINGKAT AKTIVITAS BELAJAR MAHASISWA PADA PEMAHAMAN MATERI FISIKA DASAR
}

\author{
Sulistyaning Kartikawati ${ }^{1}$, Widha Sunarno ${ }^{2}$, Suparmi ${ }^{3}$ \\ ${ }^{1}$ Program Studi Magister Pendidikan Sains FKIP Universitas Sebelas Maret \\ Surakarta, 57126, Indonesia \\ listyakartika@gmail.com \\ ${ }^{2}$ Program Studi Magister Pendidikan Sains FKIP Universitas Sebelas Maret \\ Surakarta, 57126, Indonesia \\ widhasunarno@gmail.com \\ ${ }^{3}$ Program Studi Magister Pendidikan Sains FKIP Universitas Sebelas Maret \\ Surakarta, 57126, Indonesia \\ suparmiuns@gmail.com
}

\begin{abstract}
Abstrak
Tujuan dari penelitian ini adalah untuk mengetahui: 1) perbedaan pengaruh antara pembelajaran problem posing melalui tutorial online dan tatap muka terhadap prestasi belajar Fisika Dasar II, 2) perbedaan pengaruh antara aktivitas belajar tinggi dan aktivitas belajar rendah terhadap prestasi belajar Fisika Dasar II, 3) interaksi antara pembelajaran problem posing melalui tutorial online dan tatap muka dengan aktivitas belajar tinggi dan aktivitas belajar rendah terhadap prestasi belajar Fisika Dasar II. Penelitian ini merupakan penelitian eksperimen dan dilaksanakan pada semester gasal tahun akademik 2011/2012 dengan populasi sebanyak 83 mahasiswa dengan sampel sebanyak 54 mahasiswa terdiri dari klas 3A sebanyak 26 mahasiswa dan klas 3B sebanyak 28 mahasiswa. Sampel penelitian diperoleh dengan metode random sampling. Variabel bebas penelitian adalah pembelajaran problem posing dengan tutorial online dan tatap muka, variabel terikat penelitian prestasi belajar, dan variabel moderatornya Aktivitas belajar. Data aktivitas belajar mahasiswa dikumpulkan dengan tes kuesioner dan untuk data prestasi belajar mahasiswa dikumpulkan dengan tes ujian akhir semester. Uji instrument dengan menggunakan Uji Validitas, Uji Reliabilitas, Uji Taraf Kesukaran Soal dan Uji Daya beda Soal. Data dianalisa dengan Analisa Varian (Anava) dua jalan (2x2) dengan desain factorial 2x2 dan dilanjutkan uji lanjut Anava menggunakan Microsoft excel dan minitab 15. Dari analisa data diperoleh: 1) Terdapat perbedaan pengaruh pembelajaran problem posing melalui tutorial online dan tatap muka terhadap prestasi belajar, karena $\mathrm{F}$ hitung lebih besar dari $\mathrm{F}$ tabel, 2) Terdapat perbedaan pengaruh antara mahasiswa yang memiliki aktivitas tinggi dan yang memiliki aktivitas rendah terhadap prestasi belajar, karena $\mathrm{F}$ hitung lebih besar dari F tabel, 3) Tidak terdapat interaksi antara pembelajaran problem posing melalui tutorial online dan tatap muka dengan aktivitas tinggi dan aktivitas rendah terhadap prestasi belajar, karena $\mathrm{F}$ hitung lebih kecil dari F tabel.
\end{abstract}

Kata Kunci: Pembelajaran Problem Posing, Tutorial Online dan Tatap Muka, Prestasi Belajar, Aktivitas belajar

\section{Pendahuluan}

Tujuan yang dicanangkan Program Studi Teknik Infomatika STT Dharma Iswara Madiun adalah: Mencetak sumber daya manusia yang terampil di bidang Informatika dan dapat mengaplikasikan Teknologi Informasi pada bidang - bidang lain, sesuai dengan tujuan di atas mahasiswa program studi Teknik Informatika tidak hanya terampil di bidang Informatika saja akan tetapi mahasiswa sebagai calon Sarjana Teknik Informatika harus mampu menguasai ilmu-ilmu lain seperti ilmu Fisika, ilmu Komputasi dan ilmu Matematika yang tercantum sebagai mata kuliah Kurikulum Nasional yang wajib 
diprogram oleh mahasiswa teknik. Selain itu mengapa mahasiswa Teknik Informatika harus menguasai konsep-konsep fisika secara baik, hal ini dikarenakan konsep-konsep fisika sangat mendasari semua bidang ilmu termasuk bidang Informatika.

Mata kuliah Fisika Dasar merupakan mata kuliah wajib tempuh, yang terdiri dari Fisika Dasar I dan Fisika Dasar II dengan bobot SKS masing-masing 3 SKS. Mata kuliah Fisika Dasar I dan II memiliki cakupan materi yang cukup luas sehingga bobot yang hanya 3 SKS untuk masing-masing cukup menyulitkan pencapaian ketuntasan materi sekaligus ketuntasan belajar. Hal ini terlihat dari hasil nilai ujian akhir semester Mata Kuliah Fisika Dasar I pada semester genap tahun akademik 2010/2011 mahasiswa program studi Teknik Informatika STT Dharma Iswara Madiun yang ditunjukkan pada prosentase nilai ujian akhir semester sebagai berikut: Nilai A sebesar 0\%, nilai $\mathrm{AB}$ sebesar $0 \%$, nilai $\mathrm{B}$ sebesar $10 \%$, nilai BC sebesar $15 \%$, nilai $\mathrm{C}$ sebesar $50 \%$, nilai D sebesar $20 \%$ dan nilai E sebesar 5\%

Dari hasil pengamatan untuk mata kuliah Fisika Dasar I rerata mahasiswa masih kesulitan dalam menyerap dan memahami materi Fisika Dasar I. Mahasiswa kurang dapat memahami konsep dasar fisika yang sederhana.Akibatnya dosen perlu ekstra waktu dalam menggali pengetahuan mahasiswa. Mahasiswa kesulitan dalam memahami sesuatu yang abstrak, mahasiswa masih sangat pasif dalam menggali informasi tambahan yang mendukung materi yang telah disampaikan dosen. Selama ini, dominasi dosen masih terlalu besar dalam proses pembelajaran. Model perkuliahan bersifat klasikal ditambah dengan tugas yang diberikan dosen kepada mahasiswa masih menyisakan kesulitan pada mahasiswa dalam menyerap informasi yang diberikan oleh dosen. Pembelajaran lebih menekankan pada mahasiswa untuk meniru. Ada kecenderungan dosen memberikan tugas mandiri kurang bervariasi, memberi dalam bentuk soal-soal bukan pemecahan masalah. Oleh karena itu diperlukan suatu model pembelajaran yang dapat meningkatkan daya serap, pemecahan konsep, kemampuan abstrak mahasiswa serta dapat meningkatkan aktivitas belajar mahasiswa dalam pemecahan suatu masalah fisika.

Dalam pembelajaran Fisika, penyelesaian soal-soal berperan penting dalam meningkatkan pemahaman mahasiswa sehingga tidak hanya terbatas pada mekanisme penggunaan rumus-rumus semata. Penyelesaian soal -soal dalam fisika penting untuk menuntun mahasiswa memahami pengetahuan yang abstrak. Semakin memahami pengetahuan yang abstrak serta keterkaitannya, mahasiswa akan mampu berpikir dan menyelesaikan soal-soal fisika dalam waktu yang relatif singkat. Oleh karena itu, dosen harus memberi keleluasaan berpikir bagi mahasiswa untuk menyelesaikan soal soal.

Ruseffendi (1988: 177) menyatakan, untuk membantu mahasiswa memahami soal dapat dilakukan dengan menulis kembali soal menggunakan kertas-kertas sendiri, menulis soal dalam bentuk lain, atau dalam bentuk yang lebih operasional. Suryanto (1998: 9) menyatakan secara umum untuk meningkatkan kemampuan mahasiswa dalam memecahkan masalah, salah satu cara yang dapat ditempuh adalah setiap siswa atau kelompok harus diberanikan membuat soal atau pertanyaan. Cara yang disarankan Cars dan Ruseffendi dikenal dengan istilah pengajuan soal (problem posing)

Untuk menunjang pemahaman materi dengan pemberian tugas melalui pengajuan soal (Problem Posing) juga diperlukan model pembelajaran. Selain itu upaya lain untuk melatih mahasiswa memiliki pemahaman materi adalah menggunakan berbagai media atau alat bantu pembelajaran diantaranya melalui program komputer. Heinich dkk (dalam Pribadi, 2004) mengemukakan sejumlah kelebihan penggunaan media komputer yaitu pembelajaran dengan komputer dapat menciptakan iklim belajar yang lebih efektif bagi mahasiswa yang lambat belajar dan memacu keefektifan belajar bagi mahasiswa yang cepat belajar. Pembelajaran dengan komputer termasuk didalamnya pembelajaran online memungkinkan mahasiswa dapat melakukan kegiatan belajar secara mandiri tanpa terikat oleh waktu dan 
tempat karena dapat diakses melalui internet, dapat menumbuhkan sikap positif mahasiswa terhadap materi dan proses belajar, dapat mengajarkan konsep-konsep aturan, prinsip, langkah-langkah proses dan kalkulasi yang kompleks, dapat menjelaskan konsep tersebut secara sederhana dengan penggabungan visual dan audio yang dianimasikan.

Berdasarkan hal tersebut di atas maka dapat dirumuskan permasalahan sebagai berikut

1. Bagaimana perbedaan pengaruh pembelajaran problem posing melalui tutorial online dan tatap muka terhadap prestasi belajar pada materi Fisika Dasar II

2. Bagaimana perbedaan pengaruh aktivitas belajar mahasiswa dalam mengikuti pembelajaran problem posing melalui tutorial online dan tatap muka terhadap prestasi belajar pada materi fisika dasar II

3. Bagaimana Interaksi penerapan pembelajaran problem posing melalui tutorial online dan tatap muka dengan aktivitas belajar mahasiswa terhadap prestasi belajar pada materi fisika dasar II

Tujuan yang ingin dicapai dalam penelitian ini adalah untuk mengetahui:

1. Perbandingan pengaruh pembelajaran problem posing melalui Tutorial Online dan tatap muka terhadap prestasi belajar pada materi fisika dasar II.

2. Perbandingan pengaruh aktivitas mahasiswa dalam mengikuti pembelajaran problem posing melalui tutorial online dan tatap muka terhadap prestasi belajar pada materi fisika dasar II.

3. Interaksi antara penerapan Pembelajaran problem posing melalui tutorial online dan tatap muka dengan aktivitas belajar mahasiswa terhadap prestasi belajar pada materi fisika dasar II.

\section{Metode Penelitian}

Penelitian ini mengambil lokasi di Program Studi Teknik Informatika Fakultas Teknik STT Dharma Iswara Madiun. Penelitian ini dilaksanakan pada semester gasal Tahun Akademik 2011/2012.

Dalam penelitian ini yang menjadi populasi adalah seluruh mahasiswa Teknik
Informatika STT Dharma Iswara Madiun sejumlah 82 mahasiswa terdiri dari 3 klas yaitu klas A (26 mahasiswa ), klas B (28 mahasiswa) dan klas C ( 28 mahasiswa ).

Dalam penelitian ini yang menjadi sampel adalah mahasiswa Program Studi Teknik Informatika yang memprogram matakuliah Fisika Dasar II yaitu klas A sejumlah 26 mahasiswa dan klas B sejumlah 28 mahasiswa.

Teknik pengambilan sampel dalam penelitian ini adalah Cluster Random Sampling. Materi mata kuliah dasar diasumsikan sama untuk semua sampling dan sampel yang diperoleh adalah Program studi Teknik Informatika semester 3 klas A dan klas B.

Dalam penelitian ini baik klas kontrol maupun eksperimen dikenai perlakukan, namun perlakukan yang diberikan beda. Kelompok A diberi perlakukan pembelajaran pengajuan soal (problem posing) melalui tutorial online, sedangkan kelompok B diberi perlakuan pembelajaran pengajuan soal (problem posing) melalui tatap muka. Setelah itu hasil keduanya dibandingkan, mana yang lebih baik dari kedua pembelajaran tersebut.

Dalam penelitian ini melibatkan tiga macam variabel yaitu variabel bebas pertama, variabel bebas kedua dan variabel terikat. Untuk memperjelas masing-masing variabel akan didefinisikan sebagai berikut:

Dalam penelitian ini ada tiga variabel, yaitu: a) Variabel bebas pertama (X1) adalah pembelajaran pengajuan soal (Problem Posing melalui tutorial online dan tatap muka, b) Variabel bebas kedua (X2) adalah aktivitas belajar mahasiswa, yang dibedakan dalam aktivitas tinggi dan aktivitas rendah, c) Variabel terikat (Y) adalah prestasi belajar mahasiswa pada ranah kognitif.

Terdapat 4 instrumen pada penelitian ini, yaitu: a) Angket adalah untuk mendapatkan informasi tentang aktivitas belajar mahasiswa dengan model online dan tatap muka, b) Observasi dilakukan untuk mendapatkan informasi perilaku /aktivitas mahasiswa dalam mengakses file Fisika Dasar II secara online dengan melihat learning activity report, c) Dokumentasi dipergunakan pre test Fisika 
Dasar I dengan menekankan materi penguasaan Fisika dasar I sebagai baseline pada awal perkuliahan, d) Tes digunakan dalam penelitian ini adalah tes pilihan ganda (multiple choice test). Soal yang diujikan untuk mengukur prestasi belajar yang berupa nilai dalam skala nominal.

Teknik pengumpulan data dalam penelitian ini adalah sebagai berikut :

1. Memberikan angket / kuesioner aktivitas belajar mahasiswa dalam mengikuti pembelajaran fisika secara online .

2. Memberikan evaluasi kepada mahasiswa untuk pembelajaran dengan pengajuan soal (problem Possing) melalui tutorial online maupun pembelajaran pengajuan soal (problem posing) tatap muka dalam bentuk tes tertulis.

Instrumen pelaksanaan pembelajaran dalam penelitian ini terdiri dari Silabus, SAP, dan RPP. Instrumen untuk pengambilan data pada penelitian ini ada dua macam yaitu instrumen untuk prestasi belajar dan instrumen untuk aktivitas belajar. Untuk memperoleh data prestasi belajar mahasiswa pada penelitian ini digunakan instrumen tes prestasi belajar fisika pada materi Thermodinamika berupa tes pilihan ganda dengan empat alternatif jawaban. Sedangkan untuk memperoleh data tentang keaktivitas belajar mahasiswa digunakan tes aktivitas berupa soal angket.

\section{Uji Coba Instrumen}

Dalam penelitian ini diperlukan instrumen yang memenuhi persyaratan tertentu, diantaranya adalah validitas, reliabilitas, taraf kesulitan soal dan daya beda. Sebelum penelitian dilakukan uji coba instrumen yang bertujuan untuk mengetahui tingkat validitas, reliabilitas, tingkat kesukaran dan daya beda dari instrumen tersebut. Adapun instrumen yang akan diujicobakan kepada mahasiswa meliputi soal tes prestasi belajar untuk materi Thermodinamika dan soal angket aktivitas belajar mahasiswa.

\section{Teknik Analisa Data}

Analisa data dilakukan untuk mengetahui dan menguji kebenaran hipotesis yang diajukan. Dalam penelitian ini cara untuk menganalisis data digunakan Statistik Inferial. Data dianalisis dengan Anava dua jalan dengan desain faktorial $(2 \times 2)$, namun sebelumnya dilakukan uji prasyarat yaitu uji normalitas dan uji homogenitas.

\section{Uji Prasyarat Analisis}

Uji Normalitas:

Uji normalitas digunakan untuk mengetahui apakah sampel untuk menentukan hipotesis berasal dari populasi yang terdistribusi normal atau tidak normal. Uji normalitas dalam penelitian ini menggunakan metode Lilliefors, Suharsimi Arikunto (1996).

\section{Uji Homogienitas:}

Uji ini dipakai untuk menguji apakah dua kelompok sampel dalam penelitian berasal dari populasi yang homogen atau tidak homogen. Uji Homoginetas menggunakan Rumus Farian, Suharsimi Arikunto (1996).

\section{Uji Hipotesis}

Uji Hipotesis yang digunakan adalah analisis variansi Anava dua jalan $(2 \times 2)$ frekuensi sel tidak sama. Jika pengujian prasyarat uji anava terpenuhi yaitu sampel berdistribusi normal dan homogen maka pengujian hipotesis dilakukan dengan pengujian Anava pada taraf signifikan 5\%, Suharsimi (1996). Dan apabila terjadi hubungan yang memiliki pengaruh sama dari faktor basis media pembelajaran pengajuan soal (Problem Posing) melalui tutorial online dan tatap muka terhadap prestasi mahasiswa, maka digunakan metode Scheffe untuk uji lanjut Anava. Uji lanjut Anava merupakan tindak lanjut dari analisis Anava apabila hasil dari analisis variasi menunjukkan bahwa hipotesis nol ditolak, Suharsimi Arikunto (1996).

Adapun desain faktorial penelitian adalah sebagai berikut :

\begin{tabular}{ccc}
\multicolumn{3}{c}{ Tabel 1 : Desain Faktorial Penelitian } \\
\hline $\begin{array}{c}\text { Aktivitas belajar } \\
\text { mahasiswa }\end{array}$ & Pembelajaran & Problem Posing \\
\cline { 2 - 3 } & $\begin{array}{c}\text { TutorialOnli } \\
\text { ne (A1) }\end{array}$ & Tatap Muka (A2) \\
\hline Tinggi (B1) & A1B1 & A2B1 \\
Rendah(B2) & A1B2 & A2B2 \\
\hline
\end{tabular}




\section{Hasil Penelitian dan Pembahasan}

Hasil penelitian dijabarkan dalam deskripsi data sebagai berikut:

\section{Deskripsi Data}

Data yang terkumpul dalam penelitian ini terdiri atas data aktivitas mahasiswa sebelum pembelajaran, data prestasi belajar mahasiswa sebelum pembelajaran, data aktivitas mahasiswa setelah pembelajaran dan data prestasi belajar setelah pembelajaran. Pada penelitian ini terdapat 3 variabel yaitu variabel bebas, variabel terikat dan variabel moderator. Variabel bebas pada penelitian ini adalah pembelajaran pengajuan soal (problem posing) melalui tutorial online dan tatap muka, variabel terikatnya adalah prestasi belajar mahasiswa dan variabel moderatornya adalah aktivitas belajar mahasiswa. Dalam penelitian ini sampel yang dilibatkan sebanyak 54 mahasiswa dari semester 3A dan 3B. Setelah data dari setiap variabel terkumpul selajutnya digunakan untuk uji hipotesis penelitian. Berikut deskripsi data yang diperoleh dari hasil pembelajaran:

\section{Data Prestasi Belajar mahasiswa Sebelum Pembelajaran}

Dalam penelitian ini data prestasi belajar mahasiswa sebelum pembelajaran yang digunakan yaitu data nilai rata-rata mata kuliah fisika dasar I yang dilaksanakan sebelum penelitian dilaksanakan. Deskripsi data prestasi belajar tersebut dapat ditunjukkan pada Tabel 2

Tabel 2 Deskripsi Data Prestasi Sebelum Pembelajaran

\begin{tabular}{lcccc}
\hline \multicolumn{1}{c}{ Kelpok } & $\begin{array}{c}\text { Jmlah } \\
\text { Mhs }\end{array}$ & $\begin{array}{c}\text { Nilai } \\
\text { Maks }\end{array}$ & $\begin{array}{c}\text { Nilai } \\
\text { Min }\end{array}$ & Rata-rata \\
\hline Eksp I & 26 & 79 & 50 & 62,27 \\
Eksp II & 28 & 70 & 39 & 57,00 \\
\hline
\end{tabular}

Dari Tabel 2 tentang deskripsi data prestasi mahasiswa sebelum pelaksanaan penelitian terlihat bahwa nilai maksimal untuk kelas $3 \mathrm{~A}$ sebesar 79 dan nilai minimal sebesar 50 dengan nilai rata-rata kelas sebesar 62,27. Sedangkan untuk kelas 3B diperoleh nilai maksimal sebesar 76 dan nilai minimal sebesar
39 dengan nilai rata-rata kelas sebesar 57,00. Dari data tersebut di atas terlihat bahwa kelas 3A lebih baik dibandingkan dengan kelas 3B, hal ini disebabkan karena mahasiswa dari kelas 3A lebih serius dan lebih memperhatikan dalam proses pembelajaran dibandingkan mahasiswa kelas 3B.

\section{Data Aktivitas Mahasiswa Sebelum Pembelajaran \\ Data tentang aktivitas belajar} mahasiswa diperoleh dari nilai aktivitas, selanjutnya dikelompokkan dalam 2 kategori berdasarkan rentang nilai yaitu aktivitas tinggi dan aktivitas rendah. Adapun tabel jumlah aktivitas tinggi dan aktivitas rendah sebagai berikut:

Tabel 3 Jumlah mahasiswa Aktivitas Tinggi dan Aktivitas Rendah

\begin{tabular}{ccccc}
\hline \multirow{2}{*}{ Akti } & \multicolumn{2}{c}{ Kelas 3A } & \multicolumn{2}{c}{ Kelas 3B } \\
\cline { 2 - 5 } Vitas & $\begin{array}{c}\text { Fre } \\
\text { kuensi }\end{array}$ & $\begin{array}{c}\text { Presen } \\
\text { Tase }\end{array}$ & $\begin{array}{c}\text { Fre } \\
\text { Kuens }\end{array}$ & $\begin{array}{c}\text { Presen } \\
\text { Tase }\end{array}$ \\
\hline Tinggi & 17 & 65,38 & 15 & 53,57 \\
Rendah & 9 & 34,61 & 13 & 46,42 \\
\hline Jumlah & 26 & 100 & 28 & 100 \\
\hline
\end{tabular}

Dari Tabel 3 tentang jumlah siswa aktivitas tinggi dan aktivitas rendah menunjukkan bahwa kelas 3A yang mempunyai aktivitas tinggi sebanyak 17 mahasiswa dengan prosentase sebesar $65,38 \%$ dan untuk aktivitas rendah sebanyak 9 mahasiswa dengan prosentase sebesar 34.61 $\%$. Sedangkan untuk kelas 3B yang mempunyai aktivitas tinggi sebanyak 15 mahasiswa dengan prosentase sebesar 53,57\% dan untuk aktivitas rendah sebanyak 13 mahasiswa dengan prosentase sebesar 46,42 $\%$. Dari data tersebut di atas menunjukkan bahwa kelas 3A lebih aktif dibandingkan kelas $3 \mathrm{~B}$, hal ini disebabkan karena kelas 3A kebanyakan belum bekerja sehingga disaat belajar di kelas tidak merasa malas untuk belajar.

\section{Data Prestasi Belajar Mahasiswa Setelah Pembelajaran \\ Data prestasi belajar mahasiswa} setelah pembelajaran dalam penelitian ini adalah data tes hasil belajar ranah kognitif setelah proses pembelajaran selesai. Sebaran 
data nilai hasil tes belajar ranah kognitif dari masing-masing kelompok disajikan dalam Tabel 4.

Tabel 4 data nilai hasil tes belajar ranah kognitif dari masing-masing kelompok

\begin{tabular}{ccccc}
\hline $\begin{array}{c}\text { Kelom } \\
\text { Pok }\end{array}$ & $\begin{array}{c}\text { Jumlah } \\
\text { Siswa }\end{array}$ & $\begin{array}{c}\text { Nilai } \\
\text { Mak } \\
\text { Simal }\end{array}$ & $\begin{array}{c}\text { Nilai } \\
\text { Minimal }\end{array}$ & $\begin{array}{c}\text { Rata- } \\
\text { rata }\end{array}$ \\
\hline Eksperimen I & 26 & 92 & 51 & 66,85 \\
& 28 & 75 & 49 & 63,53 \\
\hline
\end{tabular}

Dari Tabel 4 tentang data nilai hasil belajar untuk kelas dengan model pembelajaran dengan pengajuan soal (problem possing) melalui tutorial online diperoleh melalui tes yang dilakukan dengan menggunakan soal tes prestasi belajar ranah kognitif. Nilai hasil tes belajar fisika didapatkan nilai terendah 51 dan tertinggi 92 , sedangkan nilai rata-rata diperoleh 66,85 . Data nilai hasil belajar untuk kelas dengan pembelajaran pengajuan soal (problem posing) melalui tatap muka diperoleh nilai terendah 49 dan nilai tertinggi 75 , sedangkan nilai rata-rata diperoleh 63,53. Dari data tersebut di atas menunjukkan bahwa setelah dilakukan penerapan model pembelajaran nilai prestasi belajar dan nilai rata-rata kelas dari kelas 3A maupun kelas 3B mengalami peningkatan.

Sedangkan untuk destribusi frekuensi hasil belajar pada kelas dengan menggunakan pembelajaran pengajuan soal (problem posing) melalui tutorial online disajikan pada Tabel 5.

Tabel 5 Distribusi Frekuensi Hasil Belajar Kelas Problem Posing melalui Tutorial online

\begin{tabular}{ccc}
\multicolumn{3}{c}{ Posing melalui Tutorial online } \\
\hline Interval Klas & Frek & \% Frekuensi \\
& & \\
\hline $51-57$ & 1 & 3,85 \\
$58-64$ & 3 & 11,54 \\
$65-71$ & 10 & 38,46 \\
$72-78$ & 2 & 7,69 \\
$79-85$ & 6 & 23,08 \\
$86-92$ & 4 & 15,38 \\
\hline \multirow{2}{*}{ Jumlah } & 26 & 100 \\
\hline
\end{tabular}

Adapun gambar histogram hasil belajar pada kelas menggunakan pembelajaran pengajuan soal (problem posing) melalui tutorial online disajikan pada Gambar 1.

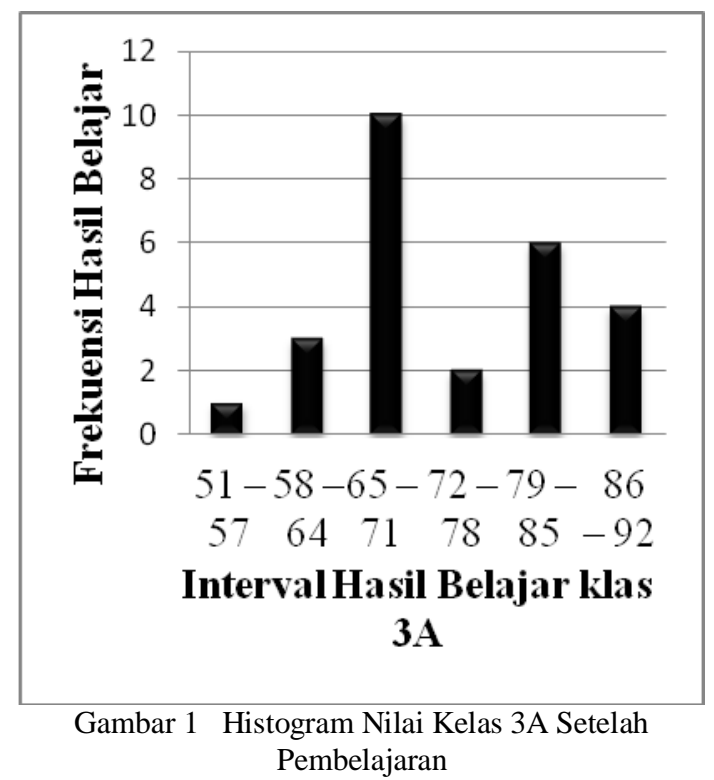

Distribusi frekuensi hasil belajar pada kelas dengan pembelajaran pengajuan soal (problem posing) melalui tatap muka disajikan pada Tabel 6.

\begin{tabular}{ccc}
$\begin{array}{c}\text { Tabel } 6 \\
\text { Distribusi Frekuensi Hasil Belajar Kelas dengan } \\
\text { problem posing melalui tatap muka }\end{array}$ \\
Interval Kelas & $\begin{array}{c}\text { Fre } \\
\text { kuensi }\end{array}$ & $\begin{array}{c}\% \text { Fre } \\
\text { kuensi }\end{array}$ \\
& 2 & 6,45 \\
$49-53$ & 9 & 29,03 \\
$54-58$ & 6 & 19,35 \\
$59-63$ & 10 & 32,26 \\
$64-68$ & 3 & 9,68 \\
$69-73$ & 1 & 3,24 \\
$74-78$ & 28 & 100 \\
\hline Jumlah & 28
\end{tabular}

Adapun gambar histogram hasil belajar pada kelas dengan pembelajaran pengajuan soal (problem posing) melalui tatap muka disajikan pada Gambar 2. 


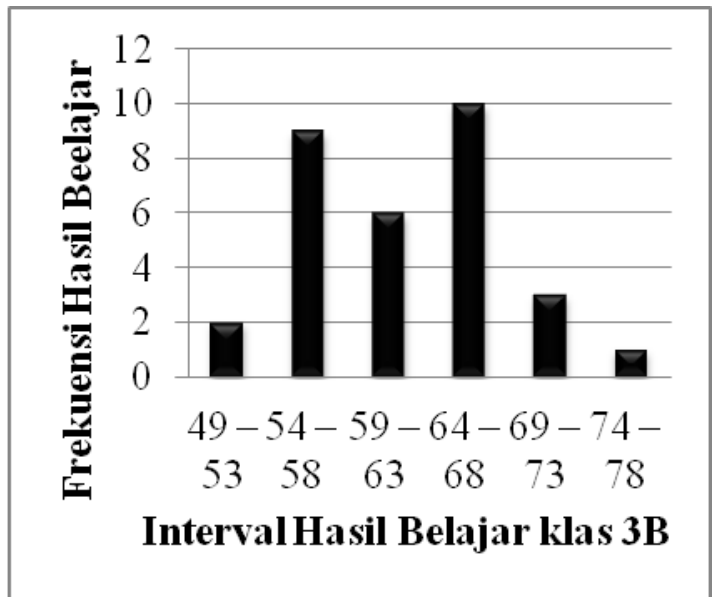

Gambar 2 Histogram Nilai Kelas 3B setelah pembelajaran

\section{Data Aktivitas Belajar Setelah Pembelajaran \\ Deskripsi data setelah pembelajaran} dengan mahasiswa yang memiliki aktivitas tinggi. Dari 26 mahasiswa sebagai responden didapatkan nilai terendah 55, nilai tertinggi 89 dan rata-ratanya adalah 71,88. Adapun distribusi frekuensi hasil belajar mahasiswa yang memiliki aktivitas tinggi disajikan pada Tabel 7.

Tabel 7 Distribusi Frekuensi Hasil Belajar Aktivitas Tinggi

\begin{tabular}{ccc}
\hline Interval Kelas & $\begin{array}{c}\text { Fre } \\
\text { kuensi }\end{array}$ & \% Frekuensi \\
\hline $55-60$ & 9 & 34,62 \\
$61-66$ & 3 & 11,54 \\
$67-72$ & 0 & 0 \\
$73-78$ & 1 & 3,85 \\
$79-84$ & 12 & 46,15 \\
$85-90$ & 1 & 3,85 \\
\hline Jumlah & 26 & 100 \\
\hline
\end{tabular}

Adapun gambar histogram hasil belajar pada kelompok mahasiswa yang memiliki aktivitas tinggi disajikan pada Gambar 3.

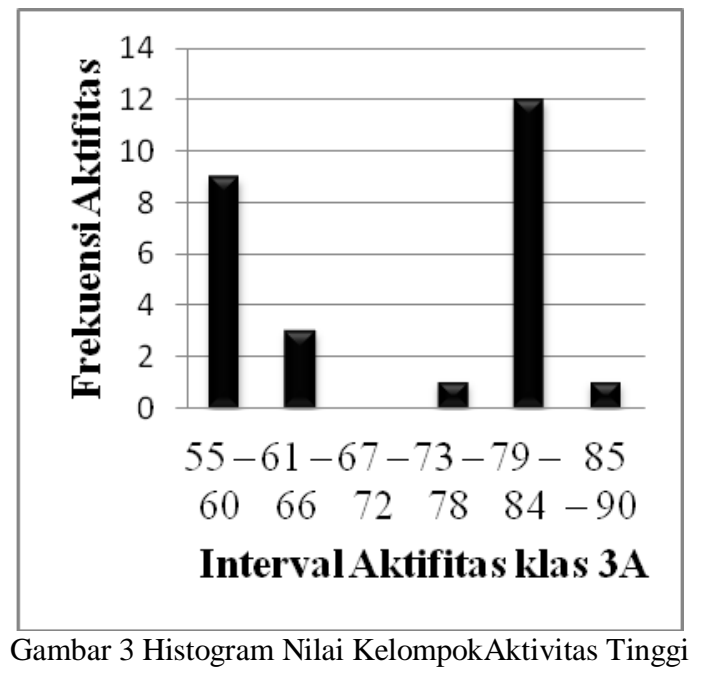

Dari Tabel 7 dan Gambar 3 tentang destribusi frekuensi serta gambar histogram menunjukkan bahwa mahasiswa kelas $3 \mathrm{~A}$ dengan aktivitas tinggi sebanyak 14 mahasiswa, sedangkan untuk aktivitas rendah sebanyak 12 mahasiswa.

Deskripsi data setelah pembelajaran mahasiswa yang memiliki aktivitas rendah.

Dari 28 mahasiswa sebagai responden didapatkan nilai terendah 55, nilai tertinggi 85 , dan rata-ratanya adalah 71,18. Adapun distribusi frekuensi hasil belajar mahasiswa yang memiliki aktivitas rendah disajikan pada Tabel 8.

$\underline{\text { Tabel } 8 \text { Distribusi Frekuensi Hasil Belajar Aktivitas Rendah }}$

\begin{tabular}{ccc} 
Interval Kelas & Frekuensi & \% Frekuensi \\
\hline $55-60$ & 11 & 35,48 \\
$61-66$ & 0 & 0 \\
$67-72$ & 0 & 0 \\
$73-78$ & 0 & 0 \\
$79-84$ & 16 & 61,29 \\
$85-90$ & 1 & 3,24 \\
\hline Jumlah & 28 & 100 \\
\hline
\end{tabular}

Adapun gambar histogram hasil belajar pada mahasiswa yang memiliki aktivitas rendah disajikan pada Gambar 4. 


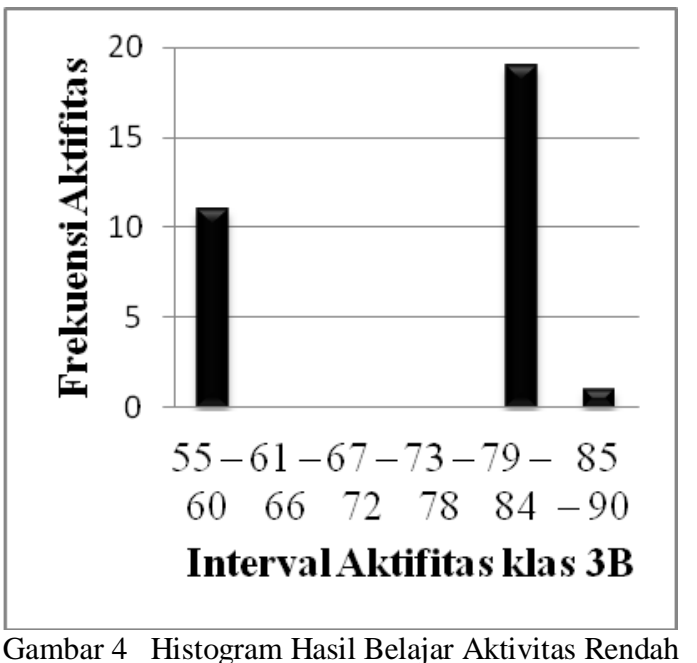

Gambar 4 Histogram Hasil Belajar Aktivitas Rendah

Dari Tabel 8 dan Gambar 4 tentang destribusi frekuensi serta gambar histogram menunjukkan bahwa mahasiswa kelas 3B dengan aktivitas tinggi sebanyak 17 mahasiswa, sedangkan untuk aktivitas rendah sebanyak 11 mahasiswa.

\section{Pengujian Prasyarat Analisis}

Uji Normalitas dan Homogenitas

\section{Uji Normalitas Sebelum Pembelajaran}

Dalam penelitian ini uji normalitas menggunakan uji normalitas Liliefors dengan tingkat signifikan 5\%. Uji normalitas ini dimaksudkan untuk mengetahui apakah sampel sebelum pembelajaran dilaksanakan berdistribusi normal. Nilai yang digunakan untuk perhitungan ini diambil dari nilai ujian akhir semester sebelum proses penelitian dilaksanakan pada kelas 3A (eksperimen I) dan pada kelas 3B (eksperimen II). Ringkasan analisisnya sebagai berikut:

\begin{tabular}{cccc}
\multicolumn{3}{c}{ Tabel 9 Uji Normalitas Sebelum Proses Pembelajaran } \\
\hline $\begin{array}{c}\text { Kelompok } \\
\text { kelas }\end{array}$ & Nilai uji & $\begin{array}{c}\text { Nilai } \\
\text { tabel }\end{array}$ & $\begin{array}{c}\text { Kete } \\
\text { Rangan }\end{array}$ \\
\hline Eksperimen I & 0,129 & 0,174 & Normal \\
Eksperimen II & 0,148 & 0,174 & Normal \\
\hline
\end{tabular}

Kelompok eksperimen I menunjukkan $\mathrm{L}_{\mathrm{obs}}=0,129$ dan kelompok eksperimen II menunjukkan $\mathrm{L}_{\mathrm{obs}}=0,148$ dengan taraf signifikansi $\alpha=5 \%$. Daerah kritik untuk uji ini adalah $\mathrm{DK}=\left\{\mathrm{L} \mid \mathrm{L}>\mathrm{L}_{0,05 ; 30}=0,174\right\}$. Hal ini berarti $\mathrm{H}_{0}$ yaitu sampel berasal dari populasi yang berdistribusi normal diterima, maka sampel untuk kelompok eksperimen I dan eksperimen II berasal dari populasi yang berdistribusi normal. Pembahasan uji normalitas untuk kelompok eksperimen I dan eksperimen II.

\section{Uji Homogenitas Sebelum Pembelajaran}

Dalam penelitian ini uji homogenitas dilakukan terhadap nilai ujian akhir semester pada kelas 3A (eksperimen I) dan pada kelas 3B (eksperimen II). Uji homogenitas digunakan untuk mengetahui apakah sampel berasal dari populasi yang homogen atau tidak. Uji homogenitas menggunakan uji $\mathrm{F}$ dengan taraf signifikan 5\%, dengan hasil yang diperoleh adalah $\mathrm{F}_{\mathrm{obs}}=1,385$. Daerah kritik untuk uji ini adalah $F_{0.05 ;(30-1),(30-1)}=F_{0.05 ; 29,29}=1,950$. Ini berarti $\mathrm{H}_{0}$ diterima sehingga dapat disimpulkan data sampel random kedua kelompok homogen.

\section{Uji Normalitas Prestasi Belajar Setelah Pembelajaran}

Dalam penelitian ini digunakan uji Liliefors dengan tingkat signifikan 5\%. Uji normalitas ini menggunakan nilai hasil tes yang dilakukan setelah proses penelitian selesai. Ringkasan analisisnya sebagai berikut:

Tabel 10 Uji Normalitas Setelah Proses Pembelajaran

\begin{tabular}{lccc}
\hline Kelompok kelas & Nilai uji & Nilai tabel & Keterangan \\
\hline Eksperimen I & 0,130 & 0,174 & Normal \\
& & & \\
Eksperimen II & 0,170 & 0,174 & Normal \\
\hline
\end{tabular}

Kelompok eksperimen I menunjukkan $\mathrm{L}_{\mathrm{obs}}=$ 0,130 dan kelompok eksperimen II menunjukkan $\mathrm{L}_{\mathrm{obs}}=0,170$ dengan taraf signifikansi $\alpha=5 \%$. Daerah kritik untuk uji ini adalah $\mathrm{DK}=\left\{\mathrm{L} \mid \mathrm{L}>\mathrm{L}_{0,05 ; 30}=0,174\right\}$. Hal ini berarti $\mathrm{H}_{0}$ yaitu sampel berasal dari populasi yang berdistribusi normal diterima, maka sampel untuk kelompok eksperimen I dan eksperimen II berasal dari populasi yang berdistribusi normal. Pembahasan uji normalitas untuk kelompok eksperimen I dan eksperimen II. 


\section{Uji Normalitas Aktivitas Mahasiswa Setelah Pembelajaran}

Uji normalitas aktivitas mahasiswa ini menggunakan uji Liliefors dengan tingkat signifikan 5\%. Ringkasan analisisnya sebagai berikut:

Tabel 11 Uji Normalitas Aktivitas siswa

\begin{tabular}{lccc}
\hline Kelompok kelas & Nilai uji & $\begin{array}{l}\text { Nilai } \\
\text { tabel }\end{array}$ & $\begin{array}{c}\text { Kete } \\
\text { Rangan }\end{array}$ \\
\hline Aktivitas tinggi & 0,190 & 0,174 & Normal \\
$\begin{array}{l}\text { Aktivitas } \\
\text { rendah }\end{array}$ & 0,250 & 0,167 & Normal \\
\hline Kelompok aktivitas tinggi & & & \\
\hline
\end{tabular}

Kelompok aktivitas tinggi menunjukkan $\mathrm{L}_{\mathrm{obs}}=$ 0,190 dengan taraf signifikansi $\alpha=5 \%$. Daerah kritik untuk uji ini adalah $\mathrm{DK}=\{\mathrm{L} \mid \mathrm{L}$ $\left.>\mathrm{L}_{0,05 ; 31}=0,174\right\}$. Kelompok aktivitas rendah menunjukkan $\mathrm{L}_{\mathrm{obs}}=0,250$ dengan taraf signifikansi $\alpha=5 \%$. Daerah kritik untuk uji ini adalah $\mathrm{DK}=\left\{\mathrm{L} \mid \mathrm{L}>\mathrm{L}_{0,05 ; 29}=0,167\right\}$. Hal ini berarti $\mathrm{H}_{0}$ yaitu sampel berasal dari populasi yang berdistribusi normal diterima, maka sampel untuk kelompok aktivitas tinggi dan kelompok aktivitas rendah berasal dari populasi yang berdistribusi normal. Pembahasan uji normalitas untuk kelompok aktivitas tinggi dan aktivitas rendah.

\section{Homogenitas Prestasi Belajar Setelah Pembelajaran}

Dalam penelitian ini uji homogenitas dilakukan terhadap tes hasil belajar mahasiswa pada kelas 3A (eksperimen I) dan pada kelas 3B (eksperimen II). Uji homogenitas digunakan untuk mengetahui apakah sampel berasal dari populasi yang homogen atau tidak. Uji homogenitas menggunakan uji $\mathrm{F}$ dengan taraf signifikan 5\%, dengan hasil yang diperoleh adalah $\mathrm{F}_{\text {obs }}=0,330$. Daerah kritik untuk uji ini adalah $F_{0.05 ;(30-1),(30-1)}=F_{0.05 ; 29,29}=1,950$. Ini berarti $\mathrm{H}_{0}$ diterima sehingga dapat disimpulkan sampel kelompok eksperimen I dan kelompok eksperimen II berasal dari populasi yang homogen.

\section{Homogenitas Aktivitas mahasiswa Setelah Pembelajaran}

Uji homogenitas digunakan untuk mengetahui apakah setiap tingkat aktivitas mempunyai variansi yang sama. Uji homogenitas menggunakan uji $\mathrm{F}$ dengan taraf signifikan 5\%, dengan hasil yang diperoleh adalah $\mathrm{F}_{\text {obs }}=1,060$. Daerah kritik untuk uji ini adalah $F_{0.05 ;(29-1),(31-1)}=F_{0.05 ; 28,30}=1,950$. Ini berarti $\mathrm{H}_{0}$ diterima sehingga dapat disimpulkan sampel kelompok aktivitas tinggi dan kelompok aktivitas rendah berasal dari populasi yang homogen.

\section{Hasil Pengujian Hipotesis}

Analisis uji prasyarat yang telah dilakukan menunjukkan bahwa data amatan pada sampel yang diambil berasal dari populasi yang berdistribusi normal serta memiliki variansi yang homogen. Hal ini berarti prasyarat untuk melakukan uji hipotesis dengan teknik uji anava dipenuhi. Rangkuman hasil uji hipotesis pada anava 2 jalan dengan sel tak sama dengan tingkat signifikan $\alpha=0,05$. Hasil analisis variansi dapat disajikan dalam tabel berikut:

Tabel 12 Rangkuman Anava Dua Jalan Dengan Sel Tak Sama

\begin{tabular}{|c|c|c|c|c|c|c|}
\hline Sumbe & JK & Dk & RK & $F_{o b s}$ & $\mathrm{~F} \alpha$ & Ho \\
\hline Antar & 342,86 & 1 & 306,81 & 6,72 & 0,013 & Ditolak \\
\hline & 84,33 & & 84,17 & & & \\
\hline Antar & & 1 & & 1,84 & 0,183 & Ditolak \\
\hline Baris & 0,00 & & & & & \\
\hline $\begin{array}{l}\text { Interak } \\
\text { si }\end{array}$ & 1734,7 & 1 & 0,00 & 0,00 & 0,999 & $\begin{array}{c}\text { Diteri } \\
\text { ma }\end{array}$ \\
\hline Dalam & 2 & 38 & $\begin{array}{c}1734,7 \\
2\end{array}$ & - & - & - \\
\hline Total & 2161,9 & 41 & - & - & - & - \\
\hline
\end{tabular}

Perhitungan berdasarkan pada Tabel 12. Hasil analisis menggunakan variansi dua jalan dengan menguji hasil tes hasil belajar ranah kognitif yang dilaksanakan setelah pembelajaran selesai didapatkan kriteria pengujian adalah Ho diterima jika $F_{o b s}<$ $\mathrm{F} \alpha$. Dan $H o$ ditolak jika $F_{o b s}>\mathrm{F} \alpha$. Hasil uji hipotesis dengan anava dua jalan diperoleh bahwa: 1) Ho1 ditolak dan $H_{i 1}$ diterima yang berarti bahwa terdapat perbedaan pengaruh pembelajaran pengajuan soal (problem posing) melalui tutorial online dan tatap muka terhadap prestasi belajar mahasiswa, 2) $\mathrm{H}_{\mathrm{o} 2}$ ditolak dan $\mathrm{H}_{\mathrm{i} 2}$ diterima yang berarti bahwa terdapat perbedaan pengaruh antara mahasiswa 
yang memiliki aktivitas belajar tinggi dengan mahasiswa yang memiliki aktivitas rendah terhadap prestasi belajar, 3) $\mathrm{H}_{03}$ diterima dan $\mathrm{H}_{\mathrm{i} 3}$ ditolak yang berarti bahwa tidak terdapat interaksi antara pembelajaran pengajuan soal (problem posing) melalui tutorial online dan tatap muka dengan aktivitas belajar tinggi dan aktivitas belajar rendah terhadap prestasi belajar mahasiswa.

Pembelajaran online ternyata memberikan hasil yang lebih baik daripada pembelajaran tatap muka sebab pembelajaran online lebih menimbulkan minat belajar mahasiswa, hal ini didorong keinginan untuk berkomunikasi dengan internet dan lebih visual karena di dalamnya terdapat animasinya. Sedangkan pada pembelajaran tatap muka pada awalnya mahasiswa belum memiliki semangat belajar baik secara mandiri maupun kelompok. Mereka masih terpancang pada perintah/tugas yang diberikan oleh dosen baik lewat bahan ajar maupun studi kasus, walaupun di dalam bahan ajar juga memberikan soal dan tugas kelompok . Hal ini bisa dimaklumi, karena mahasiswa semester awal belum dapat beradaptasi cara belajar yang efektif dan efesien pada jenjang perguruan tinggi.

\section{Uji Lanjut Anava}

Berdasarkan hasil hipotesis yang dilakukan oleh peneliti, terdapat Ho yang ditolak. Maka diputuskan untuk melakukan analisis lanjut pasca Anava dengan Menggunakan Estimated Marginal Mean. Uji ini digunakan untuk mengetahui signifikasi perbedaan pengaruh serta interaksi antar pembelajaran dengan aktivitas siswa terhadap prestasi. Uji lanjut dilakukan karena terdapat hipotesis yang ditolak sehingga perlu diketahui seberapa besar perbedaannya atau pengaruhnya terhadap variabel lain. Rangkuman hasil analisis lanjut pasca Anava ditunjukkan pada Tabel 13 berikut ini:

Tabel 13 Rangkuman hasil analisis lanjut pasca Anava

\begin{tabular}{ccccc} 
Variabel & Mean & StDev & $\begin{array}{c}\text { Nilai } \\
\text { Max }\end{array}$ & $\begin{array}{c}\text { Nilai } \\
\text { Min }\end{array}$ \\
\hline Prestasi A & 68,90 & 5,13 & 80,00 & 51,00 \\
Prestasi B & 63,19 & 8,09 & 75,00 & 56,00 \\
\hline
\end{tabular}

Berdasarkan Tabel 13 menunjukkan adanya perbedaan antara kelas $3 \mathrm{~A}$ dengan kelas 3B, sehingga dapat disimpulkan: Ada perbedaan pengaruh pembelajaran pengajuan soal (problem posing) melalui tutorial online dan pembelajaran pengajuan soal (problem posing) melalui tatap muka terhadap prestasi belajar mahasiswa. Dilihat dari nilai rataratanya, terdapat perbedaan yang signifikan antara penggunaan pembelajaran pengajuan soal (problem posing) melalui tutorial online dan tatap muka. Kelas yang diberi pembelajaran melalui tutorial online mempunyai rata-rata nilai prestasi 68,90, sedangkan untuk kelas yang diberi pembelajaran melalui tatap muka mempunyai rata-rata nilai prestasi 63,19 . Jadi kelas yang belajar melalui tutorial online berada pada posisi lebih baik dari kelas yang belajar melalui tatap muka, hal ini menunjukkan bahwa pembelajaran dengan menggunakan tutorial online lebih baik dibandingkan dengan menggunakan pembelajaran tatap muka.

\section{Pembahasan Hipotesis}

\section{Hipotesis Pertama}

$\mathrm{H}_{\mathrm{o} 1}$ : Tidak terdapat perbedaan pengaruh antara pembelajaran pengajuan soal (problem posing) melalui tutorial online dan tatap muka terhadap prestasi belajar.

$\mathrm{H}_{\mathrm{i} 1}$ : Terdapat perbedaan pengaruh antara pembelajaran pengajuan soal (problem posing) melalui tutorial online dan tatap muka terhadap prestasi belajar.

Hasil analisis uji hipotesis pada Tabel 12 Rangkuman anava menunjukkan bahwa harga $\mathrm{F}_{\text {obs }}=6,72$, sedangkan harga $\mathrm{F}_{\text {tabel }}$ pada taraf signifikansi $5 \%$ dengan $\mathrm{dk}=1$ adalah 0,013 ternyata harga $\mathrm{F}_{\mathrm{obs}}$ lebih besar dari pada harga $\mathrm{F}_{\text {tabel }}(6,72>0,013)$. Dengan demikian $H_{0 A}$ menyatakan tidak terdapat perbedaan pengaruh pembelajaran pengajuan soal (problem posing) melalui tutorial online dan tatap muka terhadap prestasi belajar fisika, ditolak. Pada saat pembelajaran dengan menggunakan pembelajaran pengajuan soal (problem posing) melalui tutorial online, mahasiswa cenderung aktif dan fokus memperhatikan penjelasan yang diberikan oleh dosen. Mahasiswa lebih aktif dalam mengajukan dan menyelesaikan 
soal setiap ada tatap muka. Suasana kelas lebih kondusif dalam proses pembelajaran yang terjadi, dimana para mahasiswa benar-benar lebih konsentrasi dan tidak malas dalam mengikuti proses pembelajaran, hal ini menunjukkan mahasiswa bersemangat mengikuti pembelajaran. Pada pembelajaran menggunakan pembelajaran pengajuan soal (problem posing) melalui tatap muka, kurang efektif untuk meningkatkan prestasi belajar mahasiswa karena mahasiswa masih belum tampak tingkat antusias dalam belajar sehingga dapat mempengaruhi prestasi belajar tidak dapat meningkat secara lebih baik. Suasana kelas pada saat proses pembelajaran cenderung tidak bersemangat serta tidak jarang ada mahasiswa yang membicarakan hal-hal lain diluar cakupan materi dan ada yang mengantuk.

\section{Hipotesis Kedua}

$\mathrm{H}_{\mathrm{o} 2}$ : Tidak terdapat perbedaan pengaruh antara mahasiswa yang memiliki aktivitas tinggi dengan mahasiswa yang memiliki aktivitas rendah terhadap prestasi belajar fisika.

$\mathrm{H}_{\mathrm{i} 2}$ :Terdapat perbedaan pengaruh antara mahasiswa yang memiliki aktivitas tinggi dengan mahasiswa yang memiliki aktivitas rendah terhadap prestasi belajar fisika.

Hasil analisis uji hipotesis pada Tabel 12 Rangkuman anava menunjukkan bahwa harga $\mathrm{F}_{\text {obs }}=1,84$ sedangkan harga $\mathrm{F}_{\text {tabel }}$ pada taraf signifikansi $5 \%$ dengan $\mathrm{dk}=1$ adalah 0,183 ternyata harga $\mathrm{F}_{\text {obs }}$ lebih besar daripada harga $\mathrm{F}_{\text {tabel }}(1,84>0,183)$. Dari data tersebut dapat disimpulkan ada perbedaan yang signifikan antara mahasiswa dengan aktivitas tinggi dan mahasiswa dengan aktivitas rendah terhadap prestasi belajar fisika. Dengan demikian $\mathrm{H}_{02}$ yang menyatakan tidak terdapat perbedaan pengaruh antara mahasiswa yang memiliki aktivitas tinggi dan mahasiswa yang memiliki aktivitas rendah terhadap prestasi belajar fisika, ditolak. Dari hasil uji hipotesis tersebut di atas menunjukkan bahwa mahasiswa yang memiliki aktivitas belajar tinggi cenderung mempunyai prestasi yang tinggi dibandingkan dengan mahasiswa yang memiliki aktivitas rendah.

\section{Hipotesis Ketiga}

$\mathrm{H}_{03}$ :Tidak terdapat interaksi antara pembelajaran pengajuan soal (problem posing) melalui tutorial online dan tatap muka terhadap prestasi belajar fisika ditinjau dari aktivitas mahasiswa.

$\mathrm{H}_{\mathrm{i} 3}$ : Terdapat interaksi antara pembelajaran pengajuan soal (problem posing) melalui tutorial online dan tatap muka terhadap prestasi belajar ditinjau dari aktivitas mahasiswa.

Dari hasil analisis uji hipotesis pada Tabel 12 Rangkuman anava menunjukkan bahwa harga $\mathrm{F}_{\text {obs }}=0,00$ sedangkan harga $F_{\text {tabel }}$ pada taraf signifikansi $5 \%$ dengan $\mathrm{dk}=1$ adalah 0,999 . Ternyata harga $\mathrm{F}_{\text {obs }}$ lebih kecil dari pada harga $F_{\text {tabel }}(0,00<0,999)$. Dengan demikian berarti $H_{03}$ yang menyatakan tidak ada interaksi antara pembelajaran pengajuan soal (problem posing) melalui tutorial online dan tatap muka terhadap prestasi belajar fisika ditinjau dari aktivitas mahasiswa, diterima. Hal tersebut dikarenakan antara penggunaan model pembelajaran dan aktivitas mahasiswa memberikan pengaruh sendiri-sendiri terhadap hasil belajar fisika. Dari uraian di atas dapat dilihat bahwa tidak ada interaksi antara pembelajaran dan aktivitas siswa ditinjau dari prestasi belajar fisika.

\section{Kesimpulan dan Rekomendasi}

1. Terdapat perbedaan pengaruh pembelajaran problem posing melalui tutorial online dengan tatap muka terhadap prestasi belajar mahasiswa yang menempuh mata kuliah Fisika Dasar II.

2. Terdapat perbedaan pengaruh antra mahasiswa yang memiliki aktivitas belajar tinggi dan aktivitas belajar rendah terhadap prestasi belajar mahasiswa yang menempuh mata kuliah Fisika Dasar II..

3. Tidak terdapat interaksi antara pembelajaran Problem Posing melalui tutorial online dengan tatap muka terhadap aktivitas belajar tinggi dan aktivitas belajar rendah terhadap prestasi belajar mahasiswa yang menempuh mata kuliah Fisika Dasar II. 
ISSN: 2252-7893, Vol. 6, No. 3, 2017 (hal 163-174)

http://jurnal.uns.ac.id/inkuiri

\section{Daftar Pustaka}

Chun - Yen Tsai. 2015: Improving Student PISA Scientific Competencies Through Online Argumentation. Int. Jour. Of Sci. Educ. 37: $2,321-339$

Canadian Center Of Science And Education. 2014. The Effects Of Problem Posing On Student Mathematical Learning. Int. Educ. Stud, Vol 7, No. 13. ISSN 1913 - 9020 E ISSN 1913 - 9039

Pribadi, 2004. Ketersediaan dan Pemanfaatan Media dan Teknologi Pembelajaran di

Perguruan Tinggi. Jurnal Pendidikan. Volume 5(2): h.145-146

2004. Prospek Komputer sebagai Media Pembelajaran Interaktif dalam Sistem Pendidikan Jarak Jauh Di Indonesia, Universitas Terbuka.

Ruseffendi, 1988. Pengajaran Matematika Modern dan Masa Kini untuk Guru dan SPG. Bandung: Tarsito.

Suharsimi. Arikunto. 1996. Prosedur Penelitian. Jakarta: PT Rineka Cipta

Suryanto. 1998. Problem Posing dalam Pembelajaran Matematika. Makalah disajikan pada Seminar Nasional: Upayaupaya Meningkatkan Peran Pendidikan dalam Menghadapi era

Globalisasi. Program Pascasarjana IKIP Malang, 4 April 1998

Zahra Ghasempour, et al. 2013: Innovation In Teaching And Learning through Problem Posing tasks And Metacognitive Strategies, International Journal Of Pedagogical Innovations, Int. J. Ped. Inn. 1, No. 1, 53 - 62 . 